\title{
Czechs revise policy on research funding, aim for a more Western approach
}

Vienna. The newly created Czech Republic plans to develop a national policy towards research and to adopt a competitive system for awarding grants. That approach is in keeping with a report issued last month by the European Communities calling for university research to be given priority in the short term and for the government to focus on applied research and technological development to achieve long-term economic health. But the report warns that the changes must be implemented gradually to avoid damaging the country's fragile research infrastructure.

Science in Czechoslovakia was well-supported under communism, with levels of spending at least 2 per cent of gross domestic product - comparable to Western Europe. But a large proportion of the money was wasted as the system had no single body responsible for an overall research strategy and gave out noncompetitive awards. Most applied research was handled by government ministries, while basic research was the responsibility of the national Academy of Sciences.

Applied research institutes were run by several different ministries and funded without regard to the quality or direction of the research; instead, political favouritism largely determined how the cake was divided. Chronically overstaffed, most of these

than 600 scientists but published on average only 12 papers a year. Even so, its funding has been reasonably well-protected since the 1989 revolution.

By contrast, industry-linked applied research institutes have fared badly. Government funding has dried up and industry, struggling to survive, has reduced its own commitment to the point where institutes are fighting over the few industrial contracts available. At least half the staff have lost their jobs.

Before 1989, the Academy of Sciences ran more than 70 institutes of varying quality. But because the money was given to the institute, rather than to a specific project, successful research did not attract extra funding. Universities received very little money for research, and only 14 of the republic's 24 institutes of higher education did any research.

Relations between the Academy of Sciences and universities have been strained since 1989. Resenting the academy's power under

institutes had questionable relevance to the needs of their parent ministries and contributed little. One institute run by the agriculture ministry, for example, employed more communism and their own lack of research facilities, the universities originally demanded the right to take over the research institutes. But the academy resisted,

\section{Prague institute leads the way}

Vienna. Ambitious plans are afoot for a centre of excellence, called the Prague Institute for Advanced Studies (PIAS), in the economically depressed capital of the new Czech Republic.

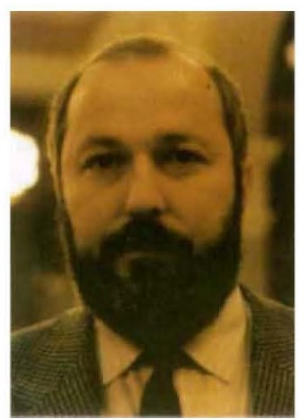

Born out of the idealism of the 1989 revolution, founded officially in 1991 , and opened for operation this year, PIAS will be dedicated to research in the life sciences and to technology transfer.

The institute was originally linked to a sister organization in Slovakia, the Slovak Applied Research Centre (SARC), that would focus on the transfer of human skills for technological development. But the two institutes have gone separate ways since the decision, now in effect, to divide Czechoslovakia into two republics. The future of SARC, which so far has a staff of only six, awaits larger decisions
about the economy by the new government of Slovakia.

\section{Peter Pechan}

Prospects for PIAS are much brighter. Three of its five planned research divisions will be established by the end of the year and are already operating with a skeleton staff. The ecological medicine group has begun to assess the effects on health of air pollution in the mining and chemical areas around Teplice in northern Bohemia. Peter Pechan, the institute's director, calls it "a model programme of cleanup to make up for our country's past". By 1995, divisions of biomedicine and imaging will join existing ones in plant biology and virology to complete the research teams.

A sixth division will organize technology transfer. PIAS has emphasized the development of intellectual property of commercial value, a new concept for the country, with researchers rewarded financially for their inventions. PIAS also wants to set up a science park that would benefit both basic research and industrial efforts.

This month, PIAS moves into a building formerly occupied by a government research institute. During the next five years, it expects to expand in size to more than 350 staff, all on short-term contracts, including collaborators from outside universities with which it intends to form close links. Its faculty will train as many as $50 \mathrm{PhD}$ students a year.

But the best of intentions can be frustrated by harsh economic reality. PIAS will not come cheap, particularly since its dream is to become financially independent. PIAS has just received ECU490,000 (US $\$ 650,000$ ) from the European Communities to cover part of its 1993 expenses. It will receive an additional ECU10.9 million later in the year to cover the capital costs of equipping laboratories. Despite those contributions, the centre will need government contributions to meet an expected annual operating shortfall of as much as ECU4 million during its first five years. 